\title{
THANGES IN THE VILNIUS, KAUNAS AND GRODNO PROVINCES PEASANTS' APPROACH TO CONSUMPTION IN THE SECOND HALF OF THE 19TH - EARLY 20TH CENTURIES
}

\section{Aelita Ambrulevičiūtè}

Vilnius University, E-mail: aelita@fan.lt

\begin{abstract}
:
This research starts from the premises that peasants as part of the emerging the Vilnius, Kaunas and Grodno provinces consumer group were most rigid, conservative, maintaining traditional, archaic lifestyles. Therefore, peasants, as the 'bottom' of absorbing the latest consumer trends, best reflected the change in the consumption patterns of a modernizing society. The theme under the investigation covers the period of $1861-1914$. The study attempts to examine the economic modernization of Vilnius, Kaunas and Grodno provinces society and rudiments of the consumer society in the second half of the 19th-early 20th centuries by taking into account the peasants' habits.
\end{abstract}

\section{Rezumat:}

Această cercetare porneşte de la premiza că grupul de consumatori ce constă în populația rurală din provinciile Vilnius, Kaunas şi Grodno a fost cel mai rigid, conservator şi cel care a păstrat cel mai mult stilul de viață tradițional şi arhaic. Aşadar, țăranii, care erau ultimii în ceea ce priveşte absorbirea ultimelor tendințe de consum, ilustrează cel mai bine tendintele de consum din societatea în curs de modernizare. Tema aleasă pentru cercetare acoperă perioada 1861-1914. Acest studiu încearcă să analizeze dezvoltarea economică a societății în provinciile Vilnius, Kaunas şi Grodno dar şi statutul societății de consum din a doua jumătate a secolului al XIX-lea - inceputul secolului XX ținând seama de obiceiurile populației rurale.

Keywords: peasants, consumption, goods, Vilnius, Kaunas, Grodno 


\section{Introduction}

Historians have been extensively studying social and economic history of the new era. A distinguishing role is played by those that examine the economic growth-inducing factors-technical progress, economic capital, method of production and change in production means, commercialization process, and so on. The studies of Western European history show a particular interest in the cognition of social and economic modernization of the Western society, as it is closely related to the current issues of today's world. Therefore, the science of history is continuously examining the evolution of economic institutions, the role of political and economic levels in the modernization of economics. ${ }^{1}$ Scholars investigate the regions of East Central Europe and Russian Empire (which incorporated Lithuania from the end of the $18^{\text {th }}$ century) and diverse reactions of the regional societies to the same challenges posed by modernization. ${ }^{2}$ The economic situation of the Russian Empire, the features of its economic policy and its implementation in different regions of the empire are explored. ${ }^{3}$ Also, historians examine various objects of material culture and expressions of human material activities, write histories of individual commodities (sugar, coffee, tea, tobacco, furniture, clothing, etc.), advertising or colours. 4

\footnotetext{
${ }^{1}$ R. Brenner, Economic Backwardness in Eastern Europe in Light of Developments in the West, The Origins of Backwardness in Eastern Europe. Economic \& Politic from the Middle Ages until the Early Twenties Century, ed. by Daniel Chirot. Berckley: University of California Press, 1989, 15-52; S. N. Eisenstadt, Tradition, Change and Modernity. New York, 1973; M. Levy, Modernization and the Structure of Societies. Princeton, NJ: Princeton University Press, 1966; B. R. Roberst, 'Peasants and Proletarians', Annual Review of Sociology, 16 (1990), 353-377; W. Rostow, The Stages of Economic Growth. Cambridge, 1960.

2 R. Bendix, Nation-Building and Citizenship: Studies of Our Changing Social Order. New York: John Wiley, 1964; C. E. Black, The Dynamics of Modernization. A Study in Comparative History. Center of International Studies, Princeton University: New York, 1967; S. P. Hungtinton, Political Order in Changing Societies. New Haven and London: Yale University Press, 1968; A. C. Janos, East Central Europe in the Modern World. The Politics of the Borderlands from Pre-to Postcommunism. Stanford University Press: Stanford, California, 2000.

${ }^{3}$ E. Brancato, Markets Versus Hierarchies: A Political Economy of Russia from the 10 $0^{\text {th }}$ Century to 2008. Eglar, Edward Publishing, Inc., 2009; A. J. Rieber, Merchants and Entrepreneurs in Imperial Russian. University of North California, 1982; A. Kappeler, Rossiya mnogonacionalnaja imperiya. Moscow, 2000.

${ }^{4}$ H. Chojnacka, Fajanse polskie XVIII-XIX wieku. Warszawa, 1981; C. MacLennan, 'The Mark of Sugar. Hawa i's Eco-Industrial Heritage', Historical Social Research, 29 (3) (2004), 37-62; F. Margot, 'Woman, consumption and couverture in England', The Historical Journal, 39 (1) (1996), 703-23; A. McCants, 'Meeting Needs and Suppressing Desires: Consumer Choise Models and Historical Data', Journal of Interdisciplinary History, XXVI:2 (Autumn, 1995), 20192
} 
The abundant studies that address the processes of economic development and material culture, in most cases, single out the research of formation and evolution of the consumer society. This theme, widely considered by the history of science, covers various aspects of the consumption development process: distribution of consumer goods, factors of mass production emergence, economic choices of workers and peasants, economic dynamism of individual levels and groups of society (women, urban, middle-class, etc.), their involvement in mass consumption. ${ }^{5}$

This article raises a problem of consumer society rudiments in the second half of the $19^{\text {th }}$ - early $20^{\text {th }}$ centuries. The object of the study is the involvement of peasants (they accounted for over $70 \%$ of the population) in mass consumption.

This research object was selected taking into consideration the fact that peasants as part of the emerging the Vilnius, Kaunas and Grodno provinces consumer group were most rigid, conservative, maintaining traditional, archaic lifestyles. Therefore, peasants, as the 'bottom' of absorbing the latest consumer trends, best reflect the change in the consumption patterns of a modernizing society.

The theme under the investigation covers a period of 1861-1914. After the partition of Poland - Lithuanian in 1795, the former Grand Duchy of Lithuania became dependent on the institutions under the tsar's administration that had an impact on all spheres of public activity, as well as the economic area. However, the empire's economic backwardness

6; L. Nalewajska, Moda męska w XIX $i$ na początku XX wieku w czasopismach ze zbioro`w Biblioteki Universyteckiej w Warsawie. Warszawa, 2008; W. Rusinski, Życie codzienne w Kaliszu. Poznan', 1988; W. H. D. Smith, 'Complication of the Commonplace: Tea, Sugar, and Imperialism', The Journal of Interdisciplinary History, 23 (2) (1995), 259-78; J. Taylor, 'Business in Pictures: Representation of Railway Enterprise in the Satirical Press in Britain 1845-1870', Past and Present 1990-2009 (A Journal of Historical Studies), vol. 189, (2005), 111-46.

5 C. Fairchilds, 'Consumption in Early Modern Europe', Comparative Studies in Society and History, 35 (4) (1993), 850-8; M. Hilton, 'The Female Consumer and the Politics of Consumption in Twenty-Century Britain', The Historical Journal, 45 (1) (2002), 103-28; J. Kocha ,'The Middle Classes in Europe', The Journal of Modern History, 67 (4) (1995), 783-806; D. Levin, 'Consumer Goods and Capitalist Modernization', The Journal of Interdisciplinary History, 22 (1) (1991), 67-77; D. Miller, 'Consumption and Commodities', Annual Review of Antropology, vol. 24, 1995, p. 141-61; E. Reed, 'The Tour de France in the Provinces: Mass Culture and Provincial Communities' Relations with the Broader World', French Historical Studies, 50 (4) (2007), 651-685; J. de Vries, The Industrial Revolution. Consumer Behavior and the Household Economy, 1650 to the Present Day. University of California at Berkley. Cambridge University Press, 2008. 
compared to the countries of western European could not ensure adequate conditions for economic development. Economic modernization had just started to gain speed when it slowed down again with more significant developments observed only after the reforms had been introduced in 1861, the most important of which was the abolition of serfdom. The reforms affected the economic development, influenced changes in the structure of the society, the spread of capitalist relations of production, the economic system of commodities, the development of factory production, the growth in production volume, etc. All these developments, in their turn, had an impact on the peasants' attitudes to consumption. The dead end was reached in 1914 when the Great War began - economic life came to a standstill and consumption possibilities reduced.

The study attempts to examine the economic modernization of Vilnius, Kaunas and Grodno provinces society and rudiments of the consumer society in the second half of the $19^{\text {th }}-$ early $20^{\text {th }}$ centuries by taking into account the peasants' habits. To achieve this aim the author sets the following objectives: 1) to investigate the features of peasants' consumption, to interpret their specifics as of a group of users, their approach to the changing economic life; 2) to determine whether the peasants' attitude to consumption was changing.

\section{Subsistence economy and consumption traditions}

In pre-industrial societies with predominant subsistence economy, manufacturing was aimed to meet the family, estate, or rural domestic needs. In this society, only a small part of surplus production remained for the market. A gradual transition to market economy relations oriented the production to commodity market while the industrial society with its dominant capitalist organization of work, started to develop mass production. Modern (industrial) capitalism not only promoted competitiveness, the division of industries and labour, urban-rural differentiation, not only turned the product into a commodity, but also led to the emergence of mass production, which, according to Max Weber has become the most important form of production in modern capitalism.

Joseph A. Schumpeter noted that generally typical outputs of capitalist production are cheap fabrics of cotton and viscose, shoes, cars, etc., rather than amenities valued by the rich. Queen Elizabeth had silk stockings. The advantage of capitalism is not the fact that the queens are 
provided with a bigger amount of pairs of silk stockings, but the fact that these stockings are made available to the girl working in a factory in exchange for a constantly decreasing amount of effort. ${ }^{6}$

In other words, upon the emergence of new technologies and the spread of factory production, the volume of industrial production increased, while owing to the decreasing production and transportation costs, the price of consumer goods was reduced making them available to less affluent population.

Taking these developments into account and looking for the right answer to the question - what could have affected the change in buying habits and consumption shift in peasants, the author suggests using the term of 'breakability'7 introduced by Jan de Vries to define 'breakable objects', meaning that goods purchased inexpensively are used for a short period of time as the market is filled with low-priced products made of cheaper, faster-wearing ('fragile, breakable') materials. By the way, de Vries does not interpret this change as the entrenchment of a declining quality standard of new goods compared to the 'sustainable' outworkers' products of pre-industrial eras. It is considered that after the Industrial Revolution, with the introduction of new technologies and the spread of mass production cheaper materials started to be used. 'The new materials also eased the introductions of stylistic elements that emphasized the differentiation of taste and fashion by design and craftsmanship' ${ }^{8}$ On the other hand, a constant supply of new quality goods stimulated consumption and expanded the demand of goods of the same function (e. g., watches). A wide price range of watches ${ }^{9}$ and a large variety of these products, sufficient enough to meet the needs of population with different

\footnotetext{
${ }^{6}$ J. A. Schumpeter, Kapitalizmas, socializmas ir demokratija (Vilnius, 1998), 79.

7 J. de Vries. The Industrial Revolutions. Consumer Behavior and the Household Economy, 1650 to the Present Day, 145.

8 Ibid.

9 Prices for watches ranged from three to several hundred rubles: 'It cannot be cheaper: instead of 22 - only 2.25 rubles; instead of gold, that cost 200 rubles, the proposed from new gold -5.25 rubles; a watch for free-just 6 rubles, the price 1.5 rubles' and so on. Classified ads: Kurjer Krajowy, 29 Dec. 1912 (11 Jan. 1913), p. 1, nr. 280, p. 6; Kurjer Litewski, 5 (18) Feb. 1908, nr. 30, p. 4; Nasza Niva, 1909, nr. 13-14, p. 208; Nasha kopeika, 3 Mar. 1910, p. 4 , 29 Jun. 1910, p. 4; Severo-Zapadnoje slovo, 4 Mar. 1899, 1 Mar. 1901, p. 4, or: 'A gold watch with a chain, which had cost 250 rubles, was stolen from Petras Vileišis, an engineer and industrialist who was living in St. George Hotel in Vilnius': see 'Proishestvije. Vilenskaja zhizn', Severo-Zapadnoje slovo, 17 Jul. 1902, p. 2.
} 
income levels and requirements, ${ }^{10}$ suggests that this product was no longer solely an attribute of people with wealthy backgrounds but became available to the less well-off, too.

Alongside with the spread of factory production, the supply of food products and industrial consumer goods was growing. As a result, the needs of the population with different income inevitably started to change (with a special increase in the demand for domestic goods). Yet, at the time when Western European countries were experiencing a factory-production "boom" and the emergence of attractive factory-produced goods on the market, poorly industrialized Lithuania was still widely using handicraft and outworkers' products of lower quality-rough, poor quality fabrics, pottery and various household items, tools and other basic necessities.

Crafting workshops focused on processing fur and leather, producing food, items of clothing, gold and silver, metal and woodwork, etc. Lots of first necessity items and basic foodstuffs were still produced by the residents themselves: bread was baked at home (as evidenced by a small amount of bread and cakes shops and a relatively higher number of grain and flour shops). The cities (not to mention towns) were still agrarian in nature: economic activity for the urban residents was an important source of livelihood as well as livestock keeping was a common thing11.

10 'A wide selection of perfect watches', 'highest quality, elegant, masculine, burnished English steel', 'the latest news from Paris', 'one famous company aiming to make watches affordable to all (in the past the price for 8 days hand-wound watch was 13 rubles and was affordable not for everyone, now costs only 3 rubles', 'a watch from genuine new gold 'DOUBLE'OR', never darkens, does not differ from 56 carat gold', etc.: see Dziennik Wilieński, nr. 4, 1907, p. 4; Nasha kopeika, 3 Mar., 29 Jun. 1910, p. 4; Severo-Zapadnoje slovo, 4 Mar. 1899, p. 4, 1 Mar. 1901, p. 4.

11 In 1859, apart from horses, that were most often used as a vehicle, in Grodno each $50^{\text {th }}$ resident kept cattle, in Bialystok - every 108th, in Dorogichin - every 6th; every 28th resident in Grodno kept a pig and a goat, in Bialystok - every 23rd resident kept a pig, every $81^{\text {st }}$ - a sheep and every 542nd - a goat; In Dorogichin - every fifth resident kept a pig and a sheep; apart from the mentioned animals, in Dorogichin every 44th resident kept a couple of working oxen and every 49 th resident-a working horse, whereas $4.1 \%$ of residents were engaged exclusively in agricultural work. Town descriptions of the 1st decade of the 20th century of Kaunas and Grodno provinces show that in Panevėžys every 31st town dweller kept a cow, every $73^{\text {rd }}$ - a sheep, 163th - a goat and every $23^{\text {rd }}-$ a pig or every 10 th town dweller had an animal, while in Zarasai a majority of residents had gardens where to satisfy their needs they grew fruit and berries. See A. Ambrulevičiūtè, 'Mažmeninè prekyba Vilniaus, Kauno ir Gardino gubernijose 1861-1914 metais (tinklas, plètra, modernèjimas)', Ph.D. diss. (University of Klaipeda, 2010), 67-68. Evidence of animal-keeping in Vilnius is supported by a complaint made in 1899 by residents against pollution of the environment and the river [Vilnelè] by sewage from about 120 cows kept in Kapanica (now 96 
Peasant farms were producing tools and other household items home-based, so only the products that could not be produced on a farm were purchased. For example, the description of the 1850-ies of Grodno province of peasant economic activity indicates that the average peasant farm's annual income was about 60 silver rubles. The nobleman during the year was paid 12 silver rubles, expenditure for the church needs - 1 ruble, precinct police chief maintenance -0.5 ruble, tool repair -3.0 ruble, wheels and sleigh repair -3.0 ruble, wooden utensils (buckets, sieves and etc.) - 1 ruble, bast (for bast-shoe production) and processed leather (shoes, gloves, harness production) purchase - 2 rubles, travel expenditures - 1 ruble, shoeing horses -3 rubles, salt ( 8 poods - pood is a unit of mass equal to 16.38 kilograms (36.11 pounds)) - about 7.5-8.0 rubles, snuff tobacco (which was more popular than smoking tobacco) - 1 ruble, shopping in fairs and markets - 2 rubles, vodka (15 buckets for 1 ruble per each) 15 rubles. Total -53 rubles, so the household was left with about 7 silver rubles. According to the author, the cost of clothing was not included into this amount because clothes were made on farms. Only gorgeous items were purchased: for men - caps, hats and belts, for women - cotton print and thin cotton for dresses, shawls, earrings, glass beads and other small items ${ }^{12}$ Another source of the $7^{\text {th }}$ decade of the $19^{\text {th }}$ century also emphasizes that for a long time the peasants were making clothes by themselves of farm-produced raw materials: 'The main production output of the population of Telšiai district - home-woven linen canvas, colored wool fabrics for women's clothing and baize for men's clothing. Although this production is not any particular business, it is surprising that people are

\footnotetext{
Polotsko street), Kinkulkin's house. The sewage was spilled through a specially made slope into the Vilnelè causing severe contamination. See 'Vilenskaja zhyzn", Severo-Zapadnoje slovo, 8 Aug., p. 2, and attempts of Skuodas town community members to discipline and fine the owners for the caused damage to the town by livestock that are released on the town streets to graze. See: Document of the public verdict of the deputies of the Telšiai District, 20 Dec. 1898: Kauno apskrities archyvas, Kaunas (hereafter KAA), f. I-49, ap., 1, b. 21014, fo. 2 .

12 However, all these little things, like money for sweets, alcohol purchase in inns and fairs, were purchased not on money assigned for farm needs, but every family member paid from his personal money. To posses their own personal resources, peasants often rented land and grew flax, from which made shirts and other clothing, and sold the surplus thus compiled personal funds. In winter, the men produced spoons, buckets, made hats, boots, gloves, etc., those who had no abilities worked as hinds. Women - were weaving by clergy, urban or richer peasants orders. See A. Kirkor, 'Byt belorusskich krestjan', in V. A. Miliutin (edc.), Vestnik Imperatorskogo russkogo geograficzeskogo obshestva, pt. ix (St Petersburg, 1853), 120-2.
} 
satisfied with home-made items and never buy foreign factory production'.13

The analysis of the economic situation data of peasant farms in Vilnius, Kaunas and Grodno provinces ${ }^{14}$ reveals a similar situation in the early $8^{\text {th }}$ decade of the $19^{\text {th }}$ century. Even well-off peasant families were making their outerwear of fabrics woven on their farm. ${ }^{15}$ During the first post-reform decades the agriculture did not acquire a commercial character, the purchasing power was poor and the peasants tried to meet their own needs from their farm's economic activity.

For example, the weaving industry development in the seventh decade in Lithuania was hindered by widespread home-based textile weaving business, mainly because the peasants satisfied their needs by domestic fabrics. ${ }^{16}$ In Grodno province of the seventh decade crafts of professional shoemakers and tailors were developing poorly. In fact, most of the population, especially in rural areas (and perhaps towns) wore bast shoes, their garments were sewn by self-taught craftsmen or peasants themselves from the farm-produced raw materials (outer clothing was made of sheep wool, underwear - of linen, bast shoes - of bast, hats - of straw and so on). ${ }^{17}$ Furthermore, house construction, items of everyday use were also made on the peasant farms (food, carpentry, various tools, etc.). With prevailing traditions of subsistence economy, farms were selling surplus of products. In the $8^{\text {th }}$ decade of the $19^{\text {th }}$ century even well-off peasants were buying only such products that were impossible to be

\footnotetext{
${ }^{13}$ Leading article, 'Oczer Telshevskogo uezda', Pamyatnaya knizhka Kovenskoi gubernii na 1862 god, pt. ii (Kaunas, 1863), 122.

14 County folk school teachers within the school operation territory were obliged under the programme prepared by the Russian Geographical Society of the Northwest section to carry out the respondents (peasants and nobles) survey. The programme included questions about landlord and peasant farms, their economic situation, the state of the industry, business of residents, etc. Also, the teacher had to provide detailed information about the economic situation of three categories of peasant farms (rich, medium and poor): family composition, income, expenses, buildings, activities, and so on. See Programma dlia sobiranija svedenij o sostojanii selskogo choziaistva i promyshlennosti (Vilno, 1872).

15 Documents of Kaunas province, 1873, describing agricultural and industrial situation in Bielsk, Aleksin, Gorodsk, Grodisk, Klesheli, Klinsk, Potokski, Zarasai, Raisk, Abromishkes Districts: Vilniaus universiteto biblioteka, Rankraščiu skyrius (Vilnius university library, Manuscript Reading Room), Vilnius (hereafter VUB), f. 34, b. 1-2, 5-9, 11, 13, 467-468.

16 K. Meškauskas, V. Puronas, M. Meškauskienè and J. Jurginis, Lietuvos pramone ikisocialistiniu laikotarpiu (Vilnius, 1976), 69.

17 Materialy po etnografii Grodnenskoj gubernii, ed. і (Вильна, 1911), 16.

98
} 
produced on a farm (salt, more rarely - sugar and tea), and items manufactured by professionals because of their higher quality (metal tools (axes, saws), agricultural machinery (scythes, tines), leather shoes, iron wrought chariot wheels and iron wrought sled), rarely - feed for animals, as well as the services of a blacksmith for tool repair. ${ }^{18}$

In subsequent decades, the change observed in the peasants' consumption habits was insignificant. It is noted that even in the early $20^{\text {th }}$ century the products not produced on a farm were available for purchase from craftsmen who 'used to sell articles on markets and fairs for money or, when buying from home, it was possible to pay in kind (in rye, wheat, potatoes, flax, wool, piglets)'.19 Therefore, even in small towns (not to mention villages) a system of exchange characteristic to subsistence economy could have survived for a longer period of time. This allowed people to meet their needs at minimum cost with the consumption of industrial production minimally reduced.

A barely industrialized Vilnius, Kaunas and Grodno provinces were reluctantly refusing subsistence economy traditions and at the beginning of the $20^{\text {th }}$ century an important source of supply, even for the citizens (not to mention the peasants), came from gardening, horticulture and animal husbandry. However, from the end of the 19th century the population gradually began to buy more food and industrial products.

This is evidenced by a growing number of stores not only in cities and towns but also in rural areas: residential sales network in small towns and villages was increasingly developed from the $9^{\text {th }}$ decade, with an increase in industrial production volume, faster commercialization of agriculture and the rise in population solvency. At that time the changes in the nature of production and the range of consumer goods triggered the change in the lifestyle of cities and towns, especially - villages. Consequently, the growth in consumption resulted in the expansion of consumer goods and food outlets. The inspection records of commerce and industry companies of Vilnius province show that at the end of the 19th early $20^{\text {th }}$ centuries, the network of shops in rural and suburban areas expanded - many villages already had shops: some of the villages had five

\footnotetext{
18 Documents of Vilnius, Kaunas, Grodno provinces, $1872-1874$, describing agricultural and industrial situation: VUB, f. 34.

19 J. Kudirka, V. Milius and A. Vyšniauskaitè, Valstiečiu verslai (Vilnius, 1983), 70.
} 
each, but the most usual number was from one to two shops (annual turnover of these shops usually reached up to 200 rubles). ${ }^{20}$

It should be noted that the product range of rural shops remained "traditional" for a long time. People traded in salt, herring, tobacco and little by little started trading in bread, sugar, tea, coffee, metal tools, kerosene, soap, fabrics, etc. While the range of products purchased was expanding and a luxury product of yesterday became of daily use today or the number of peasants able to afford factory-made goods was huge, yet in the early $20^{\text {th }}$ century the peasants were likely to meet their needs by consuming products made on their farms.

The question is - why even well-off peasants able to afford a new product did not choose the factory-made and affordable production instead of traditionally satisfying their needs from their farm's resources?

Perhaps, it can be assumed that the reasons why the peasants kept up the traditions of subsistence economy for long and avoided to absorb the consumer goods purchase and consumption practices, were not purely economic in nature. Even the economic situation of peasant serfs, the land tax burden in the post-serfdom period ${ }^{21}$, small wages of rural (and urban) workers or other factors - do not fully explain the reluctance of people of this layer to make a greater use of tradable products. The behavior of poor peasants could be explained by their uncertainty about the future, why then the well-off farmers were also buying small amounts of goods. Apparently, in order to understand the peasants' attitude to consumption, their behavior as that of a consumer should be taken into consideration.

\section{Preferences and changes in consumer behavior}

Vilnius, Kaunas and Grodno provinces were agricultural: even according to the census of 1897, peasants whose livelihood was agriculture comprised over $73 \%$ of the population ${ }^{22}$. It is common knowledge that, in case of undeveloped or poorly developed agrarian system with faulty

\footnotetext{
20 A. Ambrulevičiūtė, 'Mažmeninè prekyba Vilniaus, Kauno ir Gardino gubernijose 18611914 metais (tinklas, plètra, modernèjimas)', Ph.D. diss. (University of Klaipèda, 2010), 63.

21 After 1861 peasants paid the redemption of land, fees on public land, associations, insurance, etc. They also had to perform many duties: to give a certain amount of grain as an additional remuneration for teachers, scribes, etc., at their own expense to maintain public buildings, night guards, rural police, to ensure building lighting, heating, etc.; repair roads, carry mail, etc. See R. Vèbra, Lietuviu visuomené XIX a. antroje pusèje (Vilnius, 1990), 107. 22 Ibid. 94.
} 
cultivation tools, use of poor quality feed and low use of fertilizers, agriculture is directly dependent on climate conditions. The climate was influencing not only the harvest but also the peasant solvency, especially that of the poor as well as his standard of living. In an attempt to improve his quality of life he was forced to maximize the economic benefits, so without a permanent, even small, but steady income, a rational peasant, had to put aside part of his income "for a rainy day" in order to survive famine and barren years. Apparently, seeking to reduce the poverty effects and pile stock "for a rainy day", the farmers (especially the less well-off) used to minimize their expenses by buying only the essential goods that could not be produced on farms. Their consumption habits were moderate enough to find application even for a worn item or 'resurrect it for a second life'.

Following the principles of moderate consumption and utilitarian perception of the material world, in the environment of this category of population everyday household items were passed down from generation to generation and used to their full wear. For example, the description of a peasant position mentions that scarves and hats bought by peasants on their wedding occasion in most cases were worn by them till their senior age. ${ }^{23}$ This fact reflects their rational calculations and rational behavior: a good farmer had to save belongings and clothing as he valued efforts put for the acquisition of a new item. Unfortunately, the sources to prove this assumption are insufficient, moreover, it is unlikely to be proved by the empirical research, yet, in these particular provinces' case, we may argue that tomorrow's uncertainty and attempts to minimize risk were reducing incentives and limiting the peasants' consumption, whereas the cause of social apathy may have been the peasants' inability to satisfy their desires resulting in their indifference. In turn, the social apathy that was embracing them, which is often emphasized by scholars of the $20^{\text {th }}$ century, could have been the cause of the peasants' inactivity: 'Active [Byelorussian] is rare .... Too active Byelorussian will be ridiculed by his neighbours. He is said to have moved away from his family, seeking for foreign bread' ${ }^{24}$

In addition, an archaic way of life led in the villages, the people's old habits were maintained for long due to peasant superstition, ignorance,

${ }^{23}$ Documents of the Bielsk District, 1873, describing agricultural and industrial situation: VUB, f. 34, b. DG-11, 1. 12.

${ }^{24}$ F. Kudrinskij, ‘Byt belorussov', Vilenskij calendar `na $1905 \operatorname{god}$ (Vilna), 120. 
illiteracy. Here are a few examples: 'Chimneys are almost nowhere to be found. The smoke is passed through the windows and doors, as well as through the air holes installed behind the furnace, as a result of that, children and even adults are often sick, but the peasants do not believe it. They say: "Our parents were living that way"-and are reluctantly building chimneys". ${ }^{25}$ Reluctance or perhaps fear of "novelty" and, what is more, a hostile attitude against anything new could have also prevented from the spread of industrial goods in the village: 'People plough the soil with small, wrong plows, the new ones that are used throughout Europe are not accepted' ${ }^{26}$ It could be presumed that industrial goods were slowly entering the Lithuanian village due to the cultural attitudes of peasants: 'progress phobia', suspicious regard to 'novelty': 'In 1862 matches appeared in shops, and they were used only by town-dwellers, but even those treated matches with caution. The villagers did not have them at all at that time; some of them were unaware of that invention, others even though were aware of them, did not miss them, they could live without them. Later the matches began entering the farm-houses. They were hated and feared: hated because they needed to be bought, feared because they could cause a fire'.$^{27}$ Apparently, the peasant reservation, withdrawal and even a conservative approach to the world around, reluctance to change household lifestyle and common long-standing habits were the basis of an archaic way of life led in the villages for long. The peasants were satisfying their needs with farming resources while cash money for them was a means to pay taxes or buy things at fairs, town market or shop.

Even well-off peasants were buying few industrial goods and were maximally satisfying their needs with farming resources. Sparse historical material describing economic life in provinces suggests that subsistence economy traditions were forming a stereotype of non-consuming behavior, whereas the peasants were likely to lead a 'cost-effective' way of life ${ }^{28}$.

25 'Etnograficzeskij vzgliad na Vilenskuyu gyberniyu', Vestnik Imperatorskogo russkogo geograficzeskogo obsvzestva, pt. 20, book. 4 (1857), 251.

26 M. Valančius, Palangos Juze, in id., Raštai (Vilnius, 1977), 243.

${ }_{27}$ M. Katkus, Balanos gadyne, in id., Raštai (Vilnius, 1965), 199.

28 It may be referred to consumption habits specific to the elderly (they took over those habits from their elders who should have taken them from their parents or grandparents). Household items were bought thinking about the future, by taking into account their durability even in fairly prosperous families: coats were worn by those over 20 years of age, furniture, dishes were maintained for nearly half a century, mending of socks was a common sight and so on. The reason for that was not only because of lack of funds - the 102 
However, alongside with the changing social structure and economic situation, the peasants' views and their home environment were also changing.

The introduction of new farming techniques not only improved the quality of production but also increased the quantity - the farms of some peasants were producing surplus of goods. The spread of agricultural commercialization consolidated the layer of affluent farmers. The press of the second half of the $19^{\text {th }}$ century often mentions that the peasants were living a wealthy life ${ }^{29}$, had several and even tens of thousands of rubles of capital $^{30}$. S. Matulaitis wrote that his father had 45 hectares of land, around 1872 began construction of a new 12-room wooden house, a relative of the father-even a brick house. In 1875 Matulaitis' father and other farmers bought thresher machines, there were farmers who were buying estates. ${ }^{31}$

Alongside with the increasing incomes of farmers, their needs were also growing, stimulated by a growing supply of factory-produced consumer goods. More money was needed to buy these goods, so the farmers did not limit themselves by selling the surplus, but started consciously to produce more to the market, thus the farm was commercialized. Some of the manifestations of commercialization were described by M. Katkus: '... the production of those facilities needed money, and the money came. After the construction of Liepaja railway, farming products began to flow abroad: cereals, geese, pigs and everything else that was excessive or not excessive. That resulted in the appearance of hundreds at a more thorough farmer. In general, thirst for money, discontent, competition appeared in the society. Every year a new novelty

children undergoing education have long been supported and even the families of grandchildren were supported. Thrift, practicality were the values of the behavior, the repair of the old stuff to last long, sparing of better items for special occasions was routine: patched socks were knitted from worn and shabby jumpers, once bought dinner set was sparingly used only for special occasions, instead, cheap dishes were used; old bed sheets were used for dish-cloths, dusters, floor-mops and so on. In the Soviet Union there were no special cloths, but even in the times of global deficit the stores were selling cotton fabric for mops, rough canvas for floor cloth. However, almost no one bought them - not necessarily because of a moderate standard of living. It was unusual to buy what one could make from home resources. It was common to 'resurrect' the object for 'a new life' - tips on how to do that were published by magazines on household economy.

${ }^{29}$ J. Aitis [Staugaitis], 'Gaspadoriszki pasikalbèjimai', Szwiesa, 1890, no. 1, p. 11

30 Pamyatnaya knizhka Kovenskoi gubernii na 1897 god, pt. iv (Kovna, 1899), 363.

31 S. Matulaitis, Atsiminimai ir kiti kūriniai (Vilnius, 1957), 24-5, 28-30. 
replaces the one of the last year, life goes on, diverting sideways and without stopping'.32

A growing layer of well-off farmers in the second half of the 19th century became the channel through which novelties of a new, global industrial world were penetrating the way of life of a traditional village. Those well-off farmers wanted to demonstrate their achievements and advantages by purchasing products that were not affordable by their less well-off neighbours.

Another factor contributing to the change in the needs of rural population was the increasing migration to cities (Riga, St. Petersburg), emigration (to the United States, South Africa), and re-emigration (although there were comparatively few emigrants returning from abroad): '... people are leaving being one type, and returning to the village changed. It appears that their flat, life, clothing no longer suit them. This opinion of theirs is justified by new workshop products that are easing household work, are pouring into the hands of people: matches, lamps, forks, ploughs, spring harrows, nails, cotton fabrics, books and so on'.33 Once the man encountered a 'higher' culture, he changed and brought that 'higher culture' on his return home, as there he was interested in demonstrating his achievements and social advantage of different clothing and consumables. Subsequently, the rural way of life was filled with new consumer items, expelling home-made or handicraft products. The taste was changing at the same time.

Bast shoes, clogs or clothes sewn from hand-woven cloth looked ugly, were showing the man's poverty, low-status: 'Our people have a prevalent opinion that the things brought from elsewhere are better, stronger, cheaper, and so on. This opinion is wrong ... The Lithuanians do not like wearing home-woven clothes' ${ }^{34}$ The farmers, having appreciated the advantages of 'novelty', started gradually to absorb some of the cultural attributes of modern mode of life-clothing, household utensils and other factory-produced items: 'The residents of such villages, of course, cannot do without various things not produced in the village. One, as you see, sometimes needs some salt, another-sugar, third-kerosene, and so on. The woman again requires a needle, thread, buttons to be sewn on shirts,

\footnotetext{
32 M. Katkus, Balanos gadyne, in id., Raštai (Vilnius, 1965), 10.

33 Ibid.

34 J. Žvygas, 'Rupinkimès savaja pramonija', Vienybè, 1911, no. 42, p. 660.

104
} 
and other similar things' ${ }^{35}$ The process of satisfying the needs for novelties has expanded the demand - the need appeared not only for the improved cultivation techniques, fertilizers, etc., but also for new daily suppliesmatches, various small tools, oil lamps, and so on. The people started to appreciate not only the household items of basic necessity, but also factoryproduced clothes, shoes, dishes and even cosmetics.

At the end of the $19^{\text {th }}$ - early $20^{\text {th }}$ centuries, sustainable consumption that was bound by long-standing traditions and rationally based 'sparing' consumer behavior was juxtaposed to the new consumption trends. The perception of 'prudent' life shows that part of the population was clinging to long-standing habits, were reluctant to accept new economic decisions that seemed to them irrational. Thus with set values of being thrifty, reserved, a moderate part of the peasants were spreading the archaic customs of life while the purchase of factory-made products was seen as wastefulness because many still believed that it would be more rational to make clothes by themselves from the home-made fabrics and buy only such products that are not made on a farm.

Another example of 'sparing behavior' is found in apparently a supposed dialogue between the conservative-minded old man named Dzidorius who lived in the old tradition of sustainable consumption and a young man-'lad-servant', who has already assimilated 'short' consumption habits of the new era.

The dialogue begins with Dzidorius' complaint full of anxiety: 'Who has the youth now turned into!' 36 The conflict of values between the old and the young generations, between parents and children was triggered by changing conditions of life: 'short-term' consumer behavior taken over by the younger generation was criticized in the 19th century from the viewpoint of practical habits. The old man Dzidorius, described in the article by the author with a real prototype in mind, represents a 'long-term' or 'sustainable' consumption tradition and a pragmatic approach to things of the older generation: 'When I was growing up, when I still was a 'ladservant' my father sewed for me-'leather boots' and what do you say? I was wearing them for 25 years, sold and still got one ruble and a half. ... And what is going on now! Every 'lad-servant' annually wears off two

\footnotetext{
35 A. J., 'Krautuvèlès kaimuose', Vienybè, 1914, no. 32, p. 502.

36 Dèdè Atanazas, 'Senovès gadynèje ir dabar', Vienybè, 1910, no. 3, p. 35.
} 
pairs of leather boots and galoshes....'37. The young interlocutor, with an easy irony, mocks at such 'long-term' consumption and defends a new 'short-term' consumption practice: 'In your old times, perhaps, you had stronger leather of boots'. However, Dzidorius rudely retorts that not the things were stronger, but the people were more moderate: 'People of old times were more careful and knew how to cherish their penny. In the summer time on holidays, when going to church or returning home from church, with leather boots hanging on a stick or on the hump, we went barefoot; Well, take a look at it now: a farmhand in the middle of the summer, when the sun is heating like in the bath-house, is walking the middle of the road with gamashes or galoshes, that even dust, like smoke, is rising. And if he goes out somewhere to dance or to a wedding, his leather boots are good for nothing in one evening'. ${ }^{38}$ In his turn, the young person disagrees and asks, 'And what would cobblers do if all men wore one pair of leather shoes for 25 years?' The younger generation (of consumers) who was starting to think in categories of consumer society, adopted 'the achievements of capitalism' as a means of satisfying their whims and a self-creation tool that constructs identity. Meanwhile, the conservative-minded part of the society was seeking to protect themselves against 'capitalism achievements' that were spreading evil such as wastefulness, termination of relations with the romanticized times, refusal to wear traditional clothing.

Although a different way of life, adoption of more comfortable household mode were severely criticized by the conservative-minded society ${ }^{39}$, however, the changing economic environment led to a more frequent refusal of traditional attitudes. From the second half of the 19th century, in particular, by the end of it, under the changing socio-economic conditions a new generation of consumers emerged. The changes in consumption were obvious - a demand in consumer goods for mass consumption was increasingly growing: 'Ragged or moldy greatcoat, however national it may be, is neither at all useful to us, nor it is useful to anyone'. 40

\footnotetext{
37 Ibid. 35-6.

38 Ibid. 36.

39 Z. Medišauskinè, 'Konservatyvi visuomenès kritika XIX a. vidurio Lietuvoje', Istorija, vol. XLVI (2000), 3.

40 J. B.,' 'Iš savo pastogès', Varpas, 1900, no. 2, p. 17.

106
} 
The production of goods that were cheap and affordable to the majority of people promoted modern consumption. It 'cut off' the eternal relationship with the item, and created a short-term seasonal trend driven by consumption. This 'fashion-consciousness' typical of different consumer groups was criticized by more conservative residents. Correspondent from the economic wing newspaper "Nasha kopeika“ is surprised at the fact that even socialist press cared about fashion. The author was amazed and outraged that the workers' newspapers 'decide, argue, debate' on the fashion theme.

According to the author (that could have been a widely held opinion), it is inappropriate for the worker to follow the fashion, as ordinary clothing fits his status. The right to follow fashion was attributed only to certain ranks: aristocrats, as their origin requests, noblemen - as they differ from the townspeople and the main fashion 'consumers' affluent town dwellers. However, the epoch forced even the workers to follow the fashion, so the author asked a question - what exactly was that fashion, that equally affected both, the aristocracy, attending the theatre of brothers Westphals, and democracy, discussing the fashion trends even at the conferences of parties (Ienos parteitage)'. ${ }^{41}$ The author believes that the 'idea' of fashion comes from a female desire to 'stand out', whereas the fashion itself has turned into weakness, characteristic of both, noble ladies and female 'democrats'.

In the broad sense, not a single social stratum remained indifferent to the fashion perceived as that of the new generation's consumer lifestyle model. It was attractive to all strata, yet each of the levels identified its weaknesses in its own way. Even the above mentioned old man Dzidorius, complaining and anxious of the fact that every lad, maiden, even a pig shepherd still want to catch up with that 'fashion'42, noticed such psychological changes as wastefulness, leveling of class differences and other trends of modernizing life. In addition to the changes in the people's minds, new technologies, the emergence of 'breakable' objects in the market as well as 'shortening of the fashion lifecycle' affected the changes in the consumption behavior of peasants.

The conservative part of the society considered the increasingly modernizing material life to be a flaw of the times-'damned fashion'

\footnotetext{
${ }^{41}$ Н. Р., 'Мода'. За день, Nasha kopeika, 7 Sep. 1913, p. 2.

42 Dèdè Atanazas, 'Senovès gadynèje ir dabar', Vienybè, 1910, no. 3, p. 37.
} 
which 'consumes people today!' 43 The word 'consumes' explains the increased change and purchase of the same things under the fashion requirements, which was just wastefulness from the point of view of conservative-minded people. Earlier the furniture shifted from father to son, and an item once purchased used to serve almost the entire lifetime, for example, a cast iron pot-after its wear and tear, the purchase of such a thing looked like a shopping event, perhaps undesirable, because the repeated purchase of the worn item required additional effort: 'Once I was serving as a farmhand and took wage of 12 rubles and always had money, and you [the younger generation] you take a wage of 50 or 60 rubles and do not ever have a penny in your pocket. ... and where did this small wage of yours melt? Just on buying a pair of leather boots or galoshes?'44 Dzidorius preferred a 'sparing' behavior. In his view, to wear shoes was appropriate only in exceptional cases, for example, in church. In order to spare shoes, it was reasonable to go to church barefoot. Therefore, Dzidorius does not appreciate it when young people tend to wear shoes regularly, then shoes wear out more quickly, the whole wage is spent on new footwear. In pre-capitalist times, peasants either used to work less, or save more. So, to buy additional items, people needed extra effort which in those times was put in sparing stock or savings. For example, a certain part of peasants had saved about a thousand rubles and more of capital, which was not released into circulation ${ }^{45}$. However, the consumer lifestyle, offered by capitalism, was changing the people's conventional living environment as well as older generation's consumption skills, though the society was not yet subdued to consumption. The people were continuously purchasing not the goods they preferred but the most necessary ones.

A 'sparing' consumption behavior and a 'long-term' habit of itemconsumption are largely characteristic of societies with a low level of technology, high production costs, exhausting labour and small earnings, with comparatively expensive goods, yet, 'durable' and fashion trends that do not change for decades. Thus, prior to purchasing a new item, a rationally-minded representative of economy should draw a clear line between the 'extra effort' and a 'value of thing' or 'useful application'.

\footnotetext{
43 Ibid.

44 Ibid. 36.

45 L. Mulevičius, ‘Kauno gubernijos valstiečių ūkių biudžetai XIX a. aštuntojo dešimtmečio pradžioje', Kaimas ir dvaras Lietuvoje XIX amžiuje (Vilnius, 2003), 324.

108
} 
After weighing these options the peasant must have considered - is the replacement of a second-hand thing for the same thing, but newer, well worth the extra effort? Probably, among more renewed things there were labour tools, cultivation implements, etc., rather than everyday consumer goods (household appliances, furniture). Actually, only a moderate, restrained, reasonable and sparing farmer had a chance to survive on this side of the poverty line. However, another issue that requires more explanation is why peasants in pre-industrial period were less concerned about everyday household appliances.

A hierarchical conception of the world assigned a specific functional rank to every class and stratum in the socium structure, while the social status standards were reflected by appropriate lifestyle norms. Before class differences started to fade away or clothing style became more democratic, standards of hierarchical way of life were strictly observed-noblemen, town dwellers, peasantry. In other words, each class (or social group) was limited to the frame of certain social behavior and appearance. Nobility had to wear clothes in line with their status, use items conforming to their status.

Also, peasants wore 'peasant' clothes: 'Here it is, to the yard with a delicate horse ran a nicely dressed genteel man'. ${ }^{46}$ Another inscription is made in the customs report 'priest, dressed as peasant', 47 illustrates the tradition of how the peasant appearance was perceived and represented. This tradition was based on hierarchical provisions of the times and displayed social reservation of lower layers visible in all spheres of life.

A reserved lifestyle in a strictly hierarchical society with limited vertical social ties was aggravating social contacts between the lower and higher levels of the society. In hierarchical class society, lower social ranks that were limited within their social space, either seeking to adapt to the 'vertical' higher stratum or compete by status or demonstrate their social advantage could only afford among people of the same social level within the scope of the same social level.

The social and cultural environment of peasants was poor, 'sparing' and still relatively closed to the influences of modern times: 'People still remain dark, still in the ancient way continue building low huts and also

\footnotetext{
46 Greitakojis, 'Iš Lietuvos', Varpas, 1892, nr. 11, p. 164.

47 Document of gendarme corps notice of detained immigrants in 1870: LVIA, f. 378, PS 1870, b. 185 , fo. 319 .
} 
wear poor clothes, so that one can say-people are negligent ...",48 moreover, objects in their form, colour, appearance or the cut of the garment remained the same for decades.

In the first half of the $19^{\text {th }}$ century the peasant garments worn in summer were a coat made of canvas or homemade cloth, in wintersheepskin coat; footwear-shoes made from bast or unprocessed skins, only more wealthy wore boots. ${ }^{49}$ However, at the end of the $19^{\text {th }}$ century the uncomfortable bast shoes worn by peasants were replaced by leather boots. In the early $20^{\text {th }}$ century, the traditional clothing (long greatcoats, long shirts of knee-length, etc.) also started to change.

In the second half of the $19^{\text {th }}$-early $20^{\text {th }}$ centuries a common European fashion of short shirts spread and was permanently adopted in the western and middle regions of Lithuania. 50 There was no more ridicule of peasants 'dressed in beautiful clothes', which traditionally were worn only on special occasions and for everyday use it was common to dress modestly (even in second-hand clothes). Just some peasants, even though not immediately, did embrace 'town culture' in their way of life and took over some of its attributes: 'The farmhouse without a chimney is now a rarity. Almost everywhere in the villages the farmhouses are light, with the floor ... Folk clothing is already a rarity. Only the densest wetland is left with bast shoes. Now, it is not surprising to meet even shepherds dressed in new urban-clothing and carrying umbrellas'. ${ }^{51}$

In the middle of the $19^{\text {th }}$ century the village still lived modestly, only basic necessities were used in the household, only the minimum needs were met by the possessed household items. For example, Samogitian kitchenware looked as follows: a large copper or iron pot, some clay pots, cast iron skillet, a large elliptical bowl used for roasting mutton, lamb or piglet steaks and so on. Cutlery: made of wood, plates of clay and tin, knives and forks - with bone or wooden handles. However, forks were used only by wealthy peasants when guests were attending. Pocketknives were used while traveling, at work, outdoors or in the woods.52

\footnotetext{
48 Sodžiaus Gaidukas, 'Pakapè', Iš Lietuvos, Žemaičiu ir Lietuvos apžvalga, 1895, nr. 20, p. 159.

${ }^{49}$ Document of the description of the State manor in 1846: LVIA, f. 525, ap. 1, b. 346, fo. 54.

50 V. Kulikauskienè, XIX-XX a. Lietuvos vyru drabužiai (1. Marškinių medžiaga ir sukirpimas), Lietuvos TSR mokslu، akademijos darbai, ser. A, 3 (52) (1975), 121.

51 ‘Materialy po etnografii Grodnenskoi gubernii, ed. i (Grodno, 1911), 17.

52 Leading article, 'Byt poselian i selskoje choziaistvo', Pamyatnaya knizhka Kovenskoi gubernii na 1861 god, pt. ii (Kovno, 1862), 14.
}

110 
Nonetheless, in the early $20^{\text {th }}$ century everyday a daily peasant household abandoned wooden spoons for spoons made of aluminum, forks, and finally table knives bought from shops. ${ }^{3}$ The changes in furniture were also noticeable. At the end of the 19th century items of traditional folk furniture remained in villages that surrounded the towns or in the suburbs; the poorest people's home furnishings did not show any significant changes rough work furniture without any decorative elements. However, in the early $20^{\text {th }}$ century, the chests from peasants' household were pushed out by the wardrobes and chests of drawers, as well as by furniture, made by local carpenters - wooden couches of various forms with a back from solid wood plank, tow-stuffed or cloth-wrapped.54 The traditional decoration of Lithuanian folk furniture characteristic to the middle of the $19^{\text {th }}$ century was fading away, which may have been triggered by two factors. First, the furniture design was changing-frame solid wood and later dismantled wardrobe closets, beds were spreading. Technically, they were stronger, from the household perspective-more comfortable rather than the pieces of furniture previously used. Their design was accompanied by finished pseudo-baroque ornamental forms. The latter were considered to be a common symbol of progress. Second, the city fashion. This assertion is supported by the fact that due to the spread of baroque-style chest of drawers, in the early $20^{\text {th }}$ century people of the villages, led by that example, started to decorate dower chests. ${ }^{55}$ When examining such, at first glance minor changes the question arises as to why the farmers' taste changed.

Apparently, with the emergence of mass production-factoryproduced consumer goods, attractive and affordable products-less affluent residents when choosing clothes, shoes or a watch did not judgebeautiful-ugly, like-dislike, but evaluated whether the item is affordable and meets the consumer's needs, whether its price is in line with functions, and so on. For example, less affluent residents gave priority to such factors as the necessity to obtain a watch, its usefulness and affordability rather than its aesthetics, appeal and the like.

53 A. Daniliauskas, 'Kauno proletaru gyvenamosios patalpos XIX-XX amžiais (2. Interjero dekoras)', Lietuvos TSR mokslu ، akademijos darbai, ser. A, 3 (31) (1969), 109; Lietuviu etnografijos bruožai (Vilnius, 1964) 245, 248, 414.

54 Daniliauskas A. Kauno proletaru gyvenamosios patalpos XIX-XX amžiais, Lietuvos TSR mokslu ، akademijos darbai, ser. A, 3 (31) (1969), 110.

55 Ibid. 
The criterion of appeal influences the behavior of well-off customers when the choice is made from the goods of almost the same price range and the same function (for example, today it would be two cars of a similar class). While, less well-off strata as well as peasants were more likely to focus on the quality: the product had to be better than that produced by the outworkers' industry, or the like. It should be noted that usefulness and necessity, quality and price, prestige and status were also consumer behavior criteria in older days, yet, they did not become a driving force behind the 'consumer revolution. ${ }^{56}$

The peasants did not know, did not and were not able to follow the fashion of clothing or household goods. Household goods and clothing items targeted at them in those times were made 'forever', as strong as possible. The idea of moral aging of the good was almost non-existent: what was suitable to the father was also acceptable to his son ${ }^{57}$. However, in the long run, what was suitable to his father, no longer met the needs of the son. The analysis of these changes should involve not only 'an exploding volume of purchased goods that jump-started the growth of production in the 'leading sectors', 58 but also to understand the emergence of and spread of criteria that triggered a new type of consumer behavior and a new era of consumption among the less affluent strata of the population: aesthetics-beautiful-ugly, novelty-like-dislike, utilitynecessary-not necessary and quality-better than an outworker's made product.

More or less, these criteria were valid up to the industrial revolution, but the physical characteristics (appearance, shape, colour, quality, etc.) of consumer goods remained unchanged for decades. ${ }^{59}$

$56 \mathrm{~J}$. de Vries relates 'consumer revolution' to the appearance of 'breakable' things (breakability), when the industry changed the quality of materials and for production started to use cheaper materials, so durable items of heavy and expensive materials were replaced by items belonging to fashion cycles (shortened fashion life cycle). In this way consumption-functions of goods were separated from the asset-functions of goods: see Jan de Vries, The Industrial Revolution. Consumer Behavior and the Household Economy, 1650 to the Present Day, 129-46.

57 B. N. Mironov, Vnutrenni rynok Rossii vo vtroi polovine XVIII-pervoi polovine XIX vekov (Leningrad, 1981), 203-204.

58 J. de Vries. The Industrial Revolution. Consumer Behavior and the Household Economy, 1650 to the Present Day, 122.

59 In the 19th century Vilnius, Kaunas and Grodno provinces like in Europe, the prevailing colours in the clothing were black, brown, gray, blue and green. In the southern part of Grodno province the same brown masculine greatcoats were decorated in red or blue112 
They barely had the chance to choose, for example, a greatcoat by aesthetic criteria, whereas in the world of more or less equal pale (black, gray, blue and green) colour goods produced by craftsmen or outworkers, a new factory-made product must have looked attractive. Thus, the peasants and poorer residents may have started to apply the criteria of beautiful-ugly, like-dislike as a result of some additional factors or changes.

In Lithuania of the 19th century these factors could have been a variety of goods at affordable prices offered by mass production. In addition, the disappearance of class differences and the development of 'breakable objects' (breakability) production technology clothing started to be 'democratized' first, as peasants as well as less well-off people were involved in a game of a frequent change of items in satisfying newly emerging needs in terms of taste, fashion cycle, short-term durability and 'moral aging' of things.

Thus, when a possibility was offered to choose from goods of around the same price and functional purpose but looking aesthetically different, the lower strata of society, even though on a smaller scale, took over everyday life aesthetics characteristic to the higher strata of society. A spread of aesthetic appeal criterion among the lower strata of the population formed the consumer taste as well as consumer behavior.

trimmed cuffs and blue, green or red belts. Women decorated their brown color outerwear by wearing white (woolen), or plain blue or green (canvas) skirts, aprons with woolen red thread embroidered edges. In the western part of Bialystok province, gray and black colours were dominant, varied by occasional white or green elements. Town dwellers and former noblemen in gray-black peasant background stood out in blue and azure summer caftans and bekes overcoats with blue lapels. The author's of this source observation that this image of clothing almost did not change, the colors, despite the industry's successes were relevant even after several decades, is evidenced by the subsequent description: collar, lapels and cuffs of gray jackets are trimmed with green factory-made baize: see Materialy dlya geografii $i$ statistiki Rossii: Grodnenskaya guberniya, ed. by P. Bobrovski, pt. i (St Petersburg, 1863), 817-9; 'Materialy po etnografii Grodnenskoi gubernii, ed. i (Grodno, 1911), 23-4. In the middle of the $19^{\text {th }}$ century, black and gray color outerwear of Vilnius and Kaunas provinces was also decorated with clothing items of blue, green and red colours: see A. Kirkor, 'Etnograficzeski vzgliad na Vilneskuyu guberniyu', Etnograficzeskij sbornik izdavaiemyi Imperatorskim russkim geograficzeskim obshestvom, ed. iii (St Petersburg, 1858), 136; Leading article, 'Byt poselian i selskoje choziaistvo', Pamyatnaya knizhka Kovenskoi gubernii na 1861 god, pt. ii (Kovno, 1862), 14. Daily brown, gray and black, festive-white colour of clothing were brightened by the traditional green and red and a little later - by blue colours, yet created quite a rather dull world. 


\section{Conclusions}

In the second half of the 19 $19^{\text {th }}$ century the Vilnius, Kaunas and Grodno provinces social and economic conditions were changing as industrial production was introduced and mass-produced industrial products were spreading. The appearance of attractive industrial goods at an affordable price on the market resulted in a different consumer behavior of each social group (characterized by parameters of selection, acquisition, use, needs). The peasants' approach to use was gradually evolving, too. Consumer behavior modeled in terms of class society was promoting the acquisition and consumption of factory-produced, acquired (non-farm produced) products among peasants. The prevalence of industrial products among peasants in Lithuania could have been influenced not only by the functional purpose of products or their brand characteristics, but also by the imaginary social value of the consumption of purchased items: such a product (perhaps even in spite of its quality) automatically raised the status of the individual, reflecting his status in society, emphasized his lifestyle, property or probably, his identity.

However, in class society, due to a limited contact between social groups, a social advantage was demonstrated among socially equal people within the same social stratum. The social groups were creating an autonomous cultural environment with prevailing consumer behavior stereotypes that had emerged from within the group's socio-economic space, whereas the aesthetics of everyday life were formed under different consumption conditions.

A 'sparing' consumer behavior model common among the peasants influenced the formation of consumer skills of that group. It can be said that while peasants chose industrial production items based on utility (more efficient functionality of the product), quality inequality (comparing the outworkers' items and factory-made products), cost (if the cost conforms to the function), and similar criteria, the growing industrial demand for consumer goods did not change consumer behavior and stereotypes of 'careful' consumption.

The change in consumer behavior and stereotypes could have been influenced by replacing the criteria of utility, cost, quality differentials, etc., with new consumption habits. Apart from their rational approach to consumption, the peasants took over aesthetic and, perhaps, more individualized criteria, previously specific to the representatives of higher 
strata. In turn, the change in the priorities of peasants resulted in qualitatively new aesthetic concepts of their everyday life-a new consumer taste and a different approach to consumption.

\section{References}

\section{Archive sources}

Documents of the Bielsk District, 1873, describing agricultural and industrial situation: VUB, f. 34, b. DG-11, 1. 12.

Document of the description of the State manor in 1846: LVIA, f. 525, ap. 1, b. 346 , fo. 54 .

Documents of gendarme corps notice of detained immigrants in 1870: LVIA, f. 378, PS 1870, b. 185, fo. 319.

Documents of Kaunas province, 1873, describing agricultural and industrial situation in Bielsk, Aleksin, Gorodsk, Grodisk, Klesheli, Klinsk, Potokski, Zarasai, Raisk, Abromishkes Districts: Vilniaus universiteto biblioteka, Rankraščių skyrius (Vilnius university library, Manuscript Reading Room), Vilnius, f. 34, b. 1-2, 5-9, 11, 13, 467-468.

Document of the public verdict of the deputies of the Telšiai District, 20 Dec. 1898: Kauno apskrities archyvas, Kaunas, f. I-49, ap., 1, b. 21014 , fo. 2 .

\section{Press}

Aitis [Staugaitis], J. 'Gaspadoriszki pasikalbėjimai.' Szwiesa 1, 1890.

Atanazas, Dėdè 'Senovès gadynèje ir dabar.' Vienybé 3, 1910.

B., J. 'Iš savo pastogès.' Varpas 2, 1900.

'Byt poselian i selskoje choziaistvo.' Pamyatnaya knizhka Kovenskoi gubernii na 1861 god, pt. ii. Kovno: 1862.

Dziennik Wilieński, nr. 4, 1907.

Gaidukas, Sodžiaus. 'Pakapè', Iš Lietuvos. Žemaičiu ir Lietuvos apžvalga 20, 1895.

Greitakojis. 'Iš Lietuvos.' Varpas 11, 1892.

J., A. 'Krautuvèlès kaimuose.' Vienybé 32, 1914.

Nasha kopeika, 3 Mar., 29 Jun. 1910.

Р., Н. 'Мода' За день. Nasha kopeika, 7 Sep. 1913.

'Proishestvije. Vilenskaja zhizn', Severo-Zapadnoje slovo, 17 Jul. 1902.

Severo-Zapadnoje slovo, 1 Mar., 4 Mar. 1899.

'Vilenskaja zhyzn', Severo-Zapadnoje slovo, 8 Aug.

Žvygas, J. 'Rupinkimès savaja pramonija.' Vienybe 42, 1911. 


\section{Secondary sources}

'Etnograficzeskij vzgliad na Vilenskuyu gyberniyu.' Vestnik Imperatorskogo russkogo geograficzeskogo obsvzestva part 20 book 4 . 1857.

\section{Lietuviu etnografijos bruožai. Vilnius: 1964.}

Materialy dlya geografii i statistiki Rossii: Grodnenskaya guberniya, ed. by P. Bobrovski, pt. i. St Petersburg: 1863, 817-9.

Materialy po etnografii Grodnenskoj gubernii, ed. i. Вильна: 1911.

'Oczer Telshevskogo uezda.' Pamyatnaya knizhka Kovenskoi gubernii na 1862 god, pt. ii. Kaunas: 1863, 122.

Pamyatnaya knizhka Kovenskoi gubernii na 1897 god. pt. iv. Kovna: 1899.

Programma dlia sobiranija svedenij o sostojanii selskogo choziaistva $i$ promyshlennosti. Vilno: 1872.

Ambrulevičiūtè, A. 'Mažmeninè prekyba Vilniaus, Kauno ir Gardino gubernijose 1861-1914 metais (tinklas, plètra, modernejjimas).' Ph.D. diss. (University of Klaipèda, 2010), 67-68.

Bendix R. Nation-Building and Citizenship: Studies of Our Changing Social Order. New York: John Wiley, 1964.

Black, C. E. The Dynamics of Modernization. A Study in Comparative History. Center of International Studies, Princeton University: New York, 1967.

Brancato, E. Markets Versus Hierarchies: A Political Economy of Russia from the 10 th Century to 2008. Edward Publishing, Inc: Eglar, 2009.

Brenner, R. Economic Backwardness in Eastern Europe in Light of Developments in the West, The Origins of Backwardness in Eastern Europe. Economic $\mathcal{E}$ Politic from the Middle Ages until the Early Twenties Century, ed. by Daniel Chirot. Berckley: University of California Press, 1989, 15-52.

Chojnacka, H. Fajanse polskie XVIII-XIX wieku. Warszawa: 1981.

Daniliauskas, A. 'Kauno proletaru gyvenamosios patalpos XIX-XX amžiais (2. Interjero dekoras)', Lietuvos TSR mokslu a akademijos darbai, ser. A, 3 (31). 1969, 109.

Eisenstadt, S. N. Tradition, Change and Modernity. New York: 1973.

Fairchilds, C. 'Consumption in Early Modern Europe.' Comparative Studies in Society and History 35 (4) (1993), 850-8.

Hilton, M. 'The Female Consumer and the Politics of Consumption in 'Twenty-Century Britain.' The Historical Journal 45 (1) (2002), 103-28.

Hungtinton, S. P. Political Order in Changing Societies. New Haven and London: Yale University Press, 1968. 
Janos, A. C. East Central Europe in the Modern World. The Politics of the Borderlands from Pre-to Postcommunism. Stanford University Press: Stanford, California, 2000.

Kappeler, A. Rossiya mnogonacionalnaja imperiya. Moscow: 2000.

Katkus, M. Balanos gadyne, in id., Raštai. Vilnius: 1965.

Kirkor, A. 'Byt belorusskich krestjan', in V. A. Miliutin (edc.), Vestnik Imperatorskogo russkogo geograficzeskogo obshestva, pt.ix. St Petersburg: 1853, 120-2.

Kirkor, A. 'Etnograficzeski vzgliad na Vilneskuyu guberniyu.' Etnograficzeskij sbornik izdavaiemyi Imperatorskim russkim geograficzeskim obshestvom, ed. iii. St Petersburg: 1858.

Kocha, J. 'The Middle Classes in Europe' The Journal of Modern History 67 (4) (1995), 783-806.

Kudirka, J., V. Milius and A. Vyšniauskaitè. Valstiečiu verslai. Vilnius: 1983.

Kudrinskij, F. 'Byt belorussov', Vilenskij calendar' na 1905 god. Vilnius.

Kulikauskienė, V. XIX-XX a. Lietuvos vyrų drabužiai (1. Marškinių medžiaga ir sukirpimas), Lietuvos TSR mokslu akademijos darbai, ser. A, 3 (52), 1975.

Levin, D. 'Consumer Goods and Capitalist Modernization.' The Journal of Interdisciplinary History 22 (1) (1991), 67-77.

Levy, M. Modernization and the Structure of Societies. Princeton, NJ: Princeton University Press, 1966.

MacLennan, C. 'The Mark of Sugar. Hawa i's Eco-Industrial Heritage.' Historical Social Research 29 (3) (2004), 37-62.

Margot, F. 'Woman, consumption and couverture in England.' The Historical Journal, 39 (1) (1996), 703-23.

Matulaitis, S. Atsiminimai ir kiti küriniai. Vilnius : 1957.

McCants, A. 'Meeting Needs and Suppressing Desires: Consumer Choise Models and Historical Data.' Journal of Interdisciplinary History, XXVI:2 (Autumn, 1995), 201-6.

Medišauskinè, Z. 'Konservatyvi visuomenès kritika XIX a. vidurio Lietuvoje.' Istorija XLVI (2000), 3.

Meškauskas, K., V. Puronas, M. Meškauskienė and J. Jurginis, Lietuvos pramone ikisocialistiniu laikotarpiu. Vilnius: 1976.

Miller, D. 'Consumption and Commodities.' Annual Review of Antropology 24 (1995), 141-61.

Mironov, B. N. Vnutrenni rynok Rossii vo vtroi polovine XVIII-pervoi polovine XIX vekov. Leningrad: 1981.

Mulevičius, L. 'Kauno gubernijos valstiečių ūkių biudžetai XIX a. aštuntojo dešimtmečio pradžioje.' Kaimas ir dvaras Lietuvoje XIX amžiuje. Vilnius: 2003. 
Nalewajska, L. Moda męska w XIX i na początku XX wieku w czasopismach ze zbioro`w Biblioteki Universyteckiej w Warsawie. Warszawa, 2008.

Reed, E. 'The Tour de France in the Provinces: Mass Culture and Provincial Communities' Relations with the Broader World.' French Historical Studies 50 (4) (2007), 651-685.

Rieber, A. J. Merchants and Entrepreneurs in Imperial Russian. University of North California, 1982.

Roberst, B. R. 'Peasants and Proletarians.' Annual Review of Sociology 16 (1990), 353-377.

Rostow, W. The Stages of Economic Growth. Cambridge: CUP, 1960.

Rusinski, W. Życie codzienne w Kaliszu. Poznan', 1988.

Schumpeter, J. A. Kapitalizmas, socializmas ir demokratija, Vilnius: 1998.

Smith, W.H. D. 'Complication of the Commonplace: Tea, Sugar, and Imperialism.' The Journal of Interdisciplinary History, 23 (2) (1995), 259-78.

Taylor, J. 'Business in Pictures: Representation of Railway Enterprise in the Satirical Press in Britain 1845-1870.' Past and Present 1990-2009 (A Journal of Historical Studies) 189 (2005), 111-46.

Valančius, M. Palangos Juze, in id., Raštai. Vilnius: 1977.

Vèbra, R. Lietuviu visuomené XIX a. antroje pusejje. Vilnius: 1990.

de Vries, J. The Industrial Revolution. Consumer Behavior and the Household Economy, 1650 to the Present Day. Cambridge University Press: University of California at Berkley, 2008. 